\title{
Stentless aortic valve replacement: an update
}

\author{
This article was published in the following Dove Press journal: \\ Vascular Health and Risk Management \\ I June 201 I \\ Number of times this article has been viewed
}

\section{Junjiro Kobayashi}

Department of Cardiovascular Surgery, National Cerebral and Cardiovascular Center, Osaka, Japan
Correspondence: Junjiro Kobayashi Department of Cardiovascular Surgery, National Cerebral and Cardiovascular Center, 5-7-I Fujishiro-dai, Suita, Osaka 565-8565, Japan

Tel $+8 \mid 6683350 I 2$

Fax +8I 668727486

Email jkobayas@hsp.ncvc.go.jp
Abstract: Although porcine aortic valves or pericardial tissue mounted on a stent have made implantation techniques easier, these valves sacrifice orifice area and increase stress at the attachment of the stent, which causes primary tissue failure. Optimizing hemodynamics to prevent patient-prosthetic mismatch and improve durability, stentless bioprostheses use was revived in the early 1990s. The purpose of this review is to provide a current overview of stentless valves in the aortic position. Retrospective and prospective randomized controlled studies showed similar operative mortality and morbidity in stented and stentless aortic valve replacement (AVR), though stentless AVR required longer cross-clamp and cardiopulmonary bypass time. Several cohort studies showed improved survival after stentless AVR, probably due to better hemodynamic performance and earlier left ventricular (LV) mass regression compared with stented AVR. However, there was a bias of operation age and nonrandomization. A randomized trial supported an improved 8-year survival of patients with the Freestyle or Toronto valves compared with Carpentier-Edwards porcine valves. On the contrary, another randomized study did not show improved clinical outcomes up to 12 years. Freedom from reoperation at 12 years in Toronto stentless porcine valves ranged from $69 \%$ to $75 \%$, which is much lower than for Carpentier-Edwards Perimount valves. Cusp tear with consequent aortic regurgitation was the most common cause of structural valve deterioration. Cryolife O'Brien valves also have shorter durability compared with stent valves. Actuarial freedom from reoperation was $44 \%$ at 10 years. Early prosthetic valve failure was also reported in patients who underwent root replacement with Shelhigh stentless composite grafts. There was no level I or IIa evidence of more effective orifice area, mean pressure gradient, LV mass regression, surgical risk, durability, and late outcomes in stentless bioprostheses. There is no general recommendation to prefer stentless bioprostheses in all patients. For new-generation pericardial stentless valves, follow-up over 15 years is necessary to compare the excellent results of stented valves such as the CarpentierEdwards Perimount and Hancock II valves.

Keywords: cardiopulmonary bypass, valves, heart disease, surgery, follow-up studies

\section{Introduction}

Homografts for aortic valve replacement (AVR) were the first biologic stentless prostheses used in clinical practice in the $1960 \mathrm{~s} .{ }^{1,2}$ Binet et $\mathrm{al}^{3}$ introduced a stentless porcine bioprosthesis, but the valve was abandoned because of poor tissue fixation. Due to limited availability and a relatively difficult implantation technique, mechanical AVR became the popular therapeutic option. The disadvantage of life-long anticoagulation therapy in mechanical AVR prompted the development of xenogeneic bioprostheses. Although porcine aortic valves or pericardial tissue mounted on a stent made the 
implantation technique easier, these valves sacrificed orifice area and increased stress at the attachment of the stent, which caused earlier primary tissue failure. Optimizing hemodynamics to prevent patient-prosthetic mismatch and improve durability revived the use of stentless bioprostheses in the early 1990s. The purpose of this review is to provide a current overview of stentless valves in the aortic position.

\section{Various stentless bioprostheses and implantation technique}

First-generation stentless bioprostheses were the Freestyle valve $^{4}$ (Medtronic, Minneapolis, MN) and the Prima valve ${ }^{5}$ (Edwards Lifesciences, Irvine, CA) as well as a porcine root and fully scalloped Toronto stentless porcine valve $(\mathrm{SPV})^{6}$ (St Jude Medical, Minneapolis, MN). The O’Brien porcine stentless valve ${ }^{7}$ (CryoLife, Atlanta, GA) and Biocor porcine bioprosthesis (Biocor Industria e Pesquisa, Belo Horizonte, $\mathrm{MG}$, Brazil) ${ }^{8}$ were also introduced to the market, but have not found widespread acceptance. Subcoronary and full-root replacements are major implantation techniques. Mini-root replacement, which is an inclusion technique, has been preferred to avoid bleeding from suture lines at the aortic annulus. The advantage of subcoronary implantation is to avoid the manipulation of coronary arterial ostia. The disadvantages are difficulties occurring in the small aortic annulus and calcified aortic root, and possibilities of valve insufficiency by changing the shape of the stentless valves in a diseased aortic root. The full-root technique requires reimplantation of coronary arteries to the stentless valves. The advantage of this technique is a larger orifice area compared with the subcoronary technique, especially in patients with small aortic annulus. The full-root technique restores the physiological function of the Valsalva sinus and the sinotubular junction, as identified by da Vinci in the 15 th century. The disadvantage is the difficulty of reoperation when the aortic wall of the stentless valve calcifies.

The second generation of stentless valves improved the technical difficulties related to free-hand implantation with two rows of sutures for subcoronary implantation. The Shelhigh Super Stentless aortic porcine valve (Shelhigh, Inc, Millburn, NJ $)^{9}$ is one of the bioprostheses that require only one row of sutures. The tip of each commissure is attached to the aortic wall. This valve is mounted on a super-flexible ring, preserved with glutaraldehyde, detoxified, and heparin treated with the No-React anticalcification treatment. This valve is easier to implant and possible to use in cases of a calcified aortic wall.
The third generation of stentless valves was pericardial bioprostheses. A bovine Sorin Pericarbon Freedom ${ }^{10}$ and an equine $3 \mathrm{~F}$ heart valve ${ }^{11}$ are available in the market. These pericardial valves are flexible, easy to implant, and show an extremely good hemodynamic performance.

AVR is the treatment of choice for a vast majority of patients. However, in a subset of patients, ie, elderly patients with various comorbidities such as chronic renal failure, liver cirrhosis, chronic obstructive lung disease, and porcelain aorta, AVR is considered contraindicated because of too high predicted mortality and morbidity rates. Recent advances in valve technology have demonstrated that transcatheter aortic valve implantation is feasible and real. Edwards Sapien ${ }^{12}$ and Medtronic CoreValve ${ }^{13}$ are commercially available for transcatheter aortic valve implantation. The concept of these valves is used for new-generation sutureless stentless valves. ${ }^{14,15}$

\section{Operative outcomes}

Reports of the operative mortality of stentless and stented AVR have differed in the literature. ${ }^{16}$ Retrospective and prospective randomized controlled studies showed similar operative mortality and morbidity. Although stentless AVR required longer cross-clamp and cardiopulmonary bypass time, it did not impair the postoperative outcomes. In patients with depressed LV function, operative outcomes were better in stentless valves owing to the larger orifice area when the full-root technique was applied to avoid patient-prosthetic mismatch. ${ }^{16}$

Luciani et al ${ }^{17}$ reported survival rates after stentless and stented xenograft AVR. The stented valve was Hancock II bioprosthesis (Medtronic). Stentless bioprostheses were mainly the Biocor valve, Toronto SPV valve, and O'Brien valve. Hospital mortality was significantly $(P<0.02)$ higher in the stented group (6.2\%) than in the stentless group (2.7\%). Logistic regression analysis showed smaller aortic annulus, duration of aortic cross-clamp time, and coronary artery disease requiring coronary artery bypass as the predictive risk of hospital mortality. The stented valve was not a risk factor by itself. As a retrospective case match study, Vrandecic et al ${ }^{18}$ compared the clinical outcomes of Biocor porcine stented valves and stentless valves implanted between 1990 and 1999 . There was no significant difference in hospital mortality (stented 5.4\% and stentless $4.4 \%, P=0.79$ ).

Ali et al ${ }^{19}$ compared the Prima Plus stentless valve with the Carpentier-Edwards Perimount valve in a prospective randomized fashion. Although there was no significant difference in the mean aortic annular size, patients in the stentless group received a larger valve prosthesis $(25.3 \mathrm{~mm} \pm 2.0 \mathrm{~mm}$ versus $23.2 \mathrm{~mm} \pm 2.0 \mathrm{~mm}, P<0.001)$. Myocardial ischemic 
time and cardiopulmonary bypass time was about 30 minutes longer in the stentless group. Thirty-day mortality $(2.5 \%$ in stented valve and $3.7 \%$ in stentless valve) and postoperative morbidity were similar. Chambers et $\mathrm{al}^{20}$ compared the Toronto SPV valve with the Carpentier-Edwards Perimount valve in a prospective randomized fashion. The average labeled size of both valves was $24.7 \mathrm{~mm}$. Thirty-day mortality was $3.5 \%$ with the stented valve and $4.0 \%$ with the stentless valve, and postoperative morbidity was similar. Dunning et $\mathrm{al}^{21}$ also compared the second-generation stentless valve Sorin Freedom with the Sorin More stented valve in a prospective randomized controlled trial. Patients in the stentless group received a larger valve prosthesis $(25.7 \mathrm{~mm} \pm 2.7 \mathrm{~mm})$ than those in the stented group $(22.9 \mathrm{~mm} \pm 2.5 \mathrm{~mm})$ $(P<0.001)$. The bypass time and cross-clamp time were about 10 minutes longer in the stentless group. Thirty-day mortality was $3.2 \%$ with the stented valve and $0 \%$ with the stentless valve, and postoperative morbidity was similar.

\section{Long-term outcomes}

Long-term outcomes of various stentless bioprostheses have been reported (Table 1). ${ }^{22-30}$ Several studies showed an improved survival after stentless AVR, probably due to better hemodynamic performance and earlier LV mass regression compared with stented AVR. ${ }^{31-38}$ However, there was a bias of operation age and nonrandomization. A randomized trial supported improved survival of patients with stentless valves. Lehman et $\mathrm{al}^{39}$ compared the Freestyle or Toronto valves with Carpentier-Edwards porcine valves. Eight-year survival was significantly $(P=0.04)$ better in

Table I Comparison of stented and stentless valves

\begin{tabular}{ll}
\hline Criteria & Result \\
\hline Operative mortality & Similar \\
Early outcomes & Similar (cohort and RCT study) \\
Late outcomes & Stentless group better (Cohort study) \\
& Similar or slightly better in stentless \\
& group (RCT study) \\
Hemodynamics & Stentless better than porcine valve \\
Mean PG and EOA & Similar to pericardial valve \\
& Stented C-E Magna valve better than \\
& stentless Freestyle valve \\
& \\
LV mass regression & Better in stentless group (most cohort \\
$<6$ months & and RCT study) \\
& Similar (cohort and RCT study) \\
Burability and SVD & Better in stented group
\end{tabular}

Note: aCompared with the first-generation stentless valves.

Abbreviations: C-E, Carpentier-Edwards; EOA, effective orifice area; LV, left ventricular; PG, pressure gradient; RCT, randomized controlled trial; SVD, structural valve deterioration. the stentless group $(78.1 \% \pm 3.8 \%)$ than in the stented group $(66.0 \% \pm 4.9 \%)$. On the contrary, another randomized study did not show improved clinical outcomes for up to 12 years. Cohen et $\mathrm{al}^{40}$ compared the Toronto SPV valve with the Carpentier-Edwards Perimount valve. Freedom from valverelated morbidity at 12 years was $82 \% \pm 7 \%$ in the stented group and $55 \% \pm 7 \%$ in the stentless group $(P=0.05)$. The actuarial survival rate at 12 years was $35 \% \pm 7 \%$ in the stented group and $52 \% \pm 7 \%$ in the stentless group $(P=0.37)$. Although improved hemodynamic outcomes were obtained in patients with a Toronto SPV valve, clinical outcomes were similar in both groups.

The long-term results over more than 10 years were excellent with the Freestyle valves. ${ }^{23}$ However, the degeneration was still present in the Toronto SPV valves more than 10 years after implantation. ${ }^{24}$ Regarding structural valve deterioration and survival benefit, longer follow-up is necessary to compare the excellent results of stented valves such as the Carpentier-Edwards Perimount and Hancock II valves.

\section{Hemodynamic advantages}

LV hypertrophy and increased LV mass were highly correlated with sudden death, congestive heart failure, stroke, myocardial infarction, coronary artery disease, and other cardiovascular events. ${ }^{41}$ Incomplete regression of LV mass and LV function after AVR was also related to poor long-term survival. ${ }^{42}$ Therefore, pressure gradient across the implanted valve is one of the most important issues in AVR.

Early postoperative hemodynamic performance was not different between stentless and stented valves, though implanted valve size was larger in stented AVR. ${ }^{43-46}$ The hemodynamic advantage of stentless AVR is not unanimous, though stentless valves one size larger could be implanted if the aortic annulus has the same size. Subcoronary implantation of stentless prostheses does not necessarily allow for larger valve selection compared with stented valves, because the LV outflow suture line is within the aortic annulus. The stented valves can be placed in a supra-annular position, upsizing from the true aortic annular size. New-generation Carpentier-Edwards Perimount Magna (Edwards Lifesciences, Irvine, CA) valves had a better hemodynamic performance compared with stentless Edwards Prima Plus (Edwards Lifesciences) valves regarding pressure gradient and effective orifice area. ${ }^{47}$ No difference was found when the Prima Plus valve was compared with the Perimount pericardial valve..$^{37,48,49}$ Compared with porcine stented valves, hemodynamic performance was better with stentless valves. ${ }^{39,50,51}$ A faster and better recovery of LV function and mass 
has been reported after stentless AVR. ${ }^{36,52-57}$ Implantation technique was also related to the improved hemodynamics. A full-root technique can implant a larger stentless valve in the supra-annular position, allowing upsizing, compared with the original aortic annulus. ${ }^{58,59}$ There may be a bias in the selection of stentless or stented valves by surgeons, because more complicated aortic root anatomy leads to the more frequent selection of stented valves in the learning curve period.

In randomized studies, better hemodynamic results were obtained with Freestyle, ${ }^{57,60}$ Sorin Freedom, ${ }^{21}$ Prima Plus, ${ }^{48,61,62}$ and Toronto SPV valves ${ }^{20,43}$ compared with stented valves. Although Freestyle valves showed a greater reduction in peak velocity and a greater increased effective orifice area than Mosaic porcine valves, there was a similar reduction in LV mass index and clinical outcomes at 6 months and 12 months after the operation. ${ }^{57}$ Narang et a ${ }^{60}$ compared the Freestyle valves with Carpentier-Edwards Perimount valves. LV ejection fraction, LV mass, New York Heart Association scale, and mean pressure gradient were similar in both groups. However, in patients with LV ejection fraction less than $50 \%$ and implanted valve less than $19 \mathrm{~mm}$, there was a significant difference in LV mass index and mean pressure gradient. Sorin Freedom stentless valves had a better pressure gradient and effective orifice area than Sorin More stented valves. ${ }^{21}$ However, there was no significant difference in LV mass index at 12 months after the operation. Ali et $\mathrm{al}^{48}$ compared Prima Plus valves with Carpentier-Edwards Perimount valves. There was no difference in mean pressure gradient and LV mass 8 weeks postoperatively. Similar results were obtained by Doss et $\mathrm{al}^{61}$ and Risteski et $\mathrm{al}^{62}$ in patients over the age of 75 years. Chambers et $\mathrm{al}^{20}$ and Cohen et al ${ }^{43}$ compared Toronto SPV valves and Carpentier-Edwards Perimount valves in a randomized fashion. The effective orifice area, mean pressure gradient, and LV mass index were similar 12 months after the operation.

Stentless valves showed no pressure gradient during dobutamine stress echocardiography in comparison with elevated transvalvular gradient in mechanical valves. ${ }^{45}$ Several studies demonstrated superior hemodynamics under exercise with stentless valves compared with mechanical valves after AVR. ${ }^{63,64}$ Fries et a ${ }^{44}$ compared $23 \mathrm{~mm}$ Freestyle valves implanted by the full-root technique with native aortic valves and $23 \mathrm{~mm}$ Carpentier-Edwards Perimount valves. There was a significant increase of pressure gradient in the stented valve group under exercise, though the native valve group and the stentless valve group showed no increase in pressure gradient under exercise.
An improved hemodynamic performance resulted in faster LV mass reduction in patients with aortic stenosis and LV hypertrophy. ${ }^{65}$ A meta-analysis showed a faster LV mass reduction in patients with stentless AVR than in those with stented AVR.${ }^{52}$ However, some studies showed no differences in LV mass reduction. ${ }^{57,60-62}$ Although faster LV mass regression has been reported after stentless AVR, it was obtained by larger valve implantation, and final LV mass regression was not significant 1 year after AVR. ${ }^{21}$

\section{Degeneration and durability}

Primary tissue failure is an important issue after biological valve implantation (Table 2). Theoretically, xenogenic stentless aortic valves have better durability by avoiding stress at the stent sites. ${ }^{66}$ The hypothesis that durability is improved by avoiding tissue stress as far as the treatment method is the same as the stented counterparts cannot be proved yet. The freedom rate from structural valve deterioration of the Freestyle valves was $97 \%$ at 10 years after AVR, ${ }^{23}$ which was similar to stented AVR. ${ }^{67} \mathrm{~A}$ major cause of structural valve deterioration was cusp tear. ${ }^{68}$ Toronto SPV valve demonstrated significant degeneration and an increase in LV mass at 10-year follow-up after AVR. ${ }^{40}$ Freedom from reoperation at 12 years was $75 \%$, which is much lower than with the CarpentierEdwards Perimount valve (92\%). Cusp tear with consequent aortic regurgitation was the most common cause of structural valve deterioration. Urgent or emergent reoperation was necessary due to hemolytic anemia and congestive heart failure. The Toronto valve group also reported that 12-year freedom from reoperation AVR was as low as $69 \% .{ }^{24}$ The Carpentier-Edwards Perimount valve deteriorated with sclerosis and calcification rather than cusp tear by pathological study, ${ }^{69}$ which could permit the elective reoperation in patients of stable condition. The first-generation Cryolife O'Brien valve also has shorter durability compared with stent valves. Actuarial freedom from reoperation was $94 \%$ at 5 years and $44 \%$ at 10 years. $^{70}$ Early prosthetic valve failure was also reported in patients who underwent root replacement with the Shelhigh stentless valve and composite graft. ${ }^{71}$

The information of durability of xenogenic stentless valves in younger patients is absent because the majority of these valves are replaced in patients older than 50 years. Only Vrandecic et a ${ }^{18}$ reported the better durability of Biocor stentless bioprostheses than of its counterparts in patients with a mean age of 48.1 years and 46.1 years. Although long-term results of homograft aortic valves are excellent, faster calcification in homografts has been reported compared with Freestyle stentless valves in a younger age group. ${ }^{72}$ 
Table 2 Characteristics of various stentless valves

\begin{tabular}{|c|c|c|c|}
\hline Bioprosthesis & Company & Material and treatment & Key remarks \\
\hline O’Brien valve & CryoLife & $\begin{array}{l}\text { Porcine valve with GAH low-pressure } \\
\text { fixation }\end{array}$ & $\begin{array}{l}\text { Actuarial freedom from SVD } 91 \% \text { at } 5 \text { years } \\
\text { and } 44 \% \text { at } 10 \text { years }^{70}\end{array}$ \\
\hline Toronto SPV valve & St Jude Medical & $\begin{array}{l}\text { Porcine valve with GAH low-pressure } \\
\text { fixation }\end{array}$ & $\begin{array}{l}\text { Freedom from reoperation } 75 \% \pm 5 \% \\
\text { at } 12 \text { years }{ }^{40}\end{array}$ \\
\hline Freestyle valve & Medtronic & $\begin{array}{l}\text { Porcine aortic root with GAH } \\
\text { zero-pressure fixation with } \\
\text { amino oleic acid treatment }\end{array}$ & $\begin{array}{l}\text { Actuarial freedom from SVD } 97.0 \% \pm 2.2 \% \\
\text { (subcoronary), } 96.0 \% \pm 4.5 \% \text { (full root), } \\
\text { and } 90.9 \% \pm 11.2 \% \text { (root inclusion) at } 10 \text { years, }{ }^{23} \\
\text { but deteriorate thereafter }{ }^{68}\end{array}$ \\
\hline Prima Plus valve & Edwards Lifesciences & $\begin{array}{l}\text { Porcine aortic root with GAH low- } \\
\text { pressure fixation and XenoLogiX } \\
\text { anticalcification treatment }\end{array}$ & $\begin{array}{l}\text { Actuarial survival rate } 71.5 \% \text { at } 8 \text { years } \\
\text { and freedom from SVD } 97.8 \% \text { at } 8 \text { years }{ }^{25}\end{array}$ \\
\hline Biocor stentless valve & St Jude Medical & $\begin{array}{l}\text { Porcine valve sutured to a GAH- } \\
\text { treated bovine pericardial conduit }\end{array}$ & $\begin{array}{l}\text { Freedom from reoperation } 98.9 \% \pm 0.7 \% \\
\text { at } 9 \text { years }^{18}\end{array}$ \\
\hline $\begin{array}{l}\text { Pericarbon freedom } \\
\text { valve }\end{array}$ & Sorin Biomedica & $\begin{array}{l}\text { Bovine pericarial valve composed } \\
\text { of two sheets sutured together, } \\
\text { GAH treated, and detoxificated } \\
\text { with homocysteic acid }\end{array}$ & $\begin{array}{l}\text { Freedom from valve-related death and } \\
\text { reoperation } 91 \% \pm 4 \% \text { and } 94 \% \pm 4 \% \text { at } 7 \text { years } \\
\text { No structural valve deterioration observed }{ }^{10}\end{array}$ \\
\hline Super-stentless valve & Shelhigh & $\begin{array}{l}\text { Porcine valve mounted on a } \\
\text { superflexible ring with GAH and } \\
\text { No-React anticalcification treatment }\end{array}$ & $\begin{array}{l}\text { Possible contamination and malfuction warning } \\
\text { by the US Food and Drug Administration }{ }^{71}\end{array}$ \\
\hline $\begin{array}{l}3 \mathrm{~F} \text { Therapeutics } \\
\text { stentless valve }\end{array}$ & ATS Medical & $\begin{array}{l}\text { Equine pericardial tubular valve } \\
\text { treated with bufferd formulation } \\
\text { of GAH fixation }\end{array}$ & Large effective orifice area $\left(1.7 \mathrm{~cm}^{2}\right)^{11}$ \\
\hline
\end{tabular}

Abbreviations: GAH, glutaraldehyde; SVD, structural valve deterioration.

\section{Recommended indication of stentless valves}

Homografts have been believed to be the substitute of choice in patients with active infective endocarditis. However, there was no difference in susceptibility to infection between homografts and mechanical valves. ${ }^{73}$ Several reports of cures for infective endocarditis with stentless valves have been demonstrated as the substitute of the homograft, ${ }^{74-76}$ which is not easily available in many countries.

Stentless bioprostheses were thought to replace stented biological valves by better hemodynamic performance and longer durability when they were introduced in the early 1990s. In 2008, less than $12 \%$ of all aortic valve prostheses implanted in Europe were stentless. ${ }^{49}$ The low percentage of stentless valves was attributed to similar hemodynamic performance and easier implanting technique of new-generation bioprostheses such as Carpentier-Edwards Perimount Magna valve and Medtronic Mosaic Ultra valve. The durability of long-term outcomes was not better than expected. A demanding, cumbersome technique prolongs cardiac ischemic and bypass time and increases risk to the patient. Most surgeons now tend to implant stented valves in complicated cases and octogenarians, knowing that operative mortality and durability are not worse than with stentless AVR. Stentless valves with an easier implantation technique (one suture line or sutureless) may increase the market of stentless bioprostheses in the future.

There was no level I or IIa evidence of better hemodynamic performance, LV mass regression, surgical risk, durability, and late outcomes. At present, stentless bioprostheses are recommended in relatively young and active patients with impaired LV function and small aortic annulus. There is no general recommendation to prefer stentless bioprostheses in all patients.

Bioprostheses for transcatheter aortic valve implantation does not have long-term outcomes. ${ }^{12,13}$ Following the previous literature on stentless valves, modification of stentless bioprostheses used in the transcatheter technique should be restricted to patients with serious comorbidity or octogenarians contraindicated to standard AVR. Autologous pericardial stentless valves should also be limited to younger age groups of patients aged less than 50 years. ${ }^{77}$

\section{Disclosure}

The author discloses no conflicts of interest.

\section{References}

1. Ross DN. Aortic valve replacement. Lancet. 1966;27:461-463.

2. Barrat-Boyes BG. Homograft aortic replacement in aortic incompetence and stenosis. Thorax. 1964;19:131-150.

3. Binet JP, Duran CCT, Carpentier A, et al. Heterologous aortic valve transplantation. Lancet. 1965;2:1275-1276. 
4. Kon ND, Westaby S, Amarasena N, et al. Comparison of implant techniques using the Freestyle stentless porcine aortic valve. Ann Thorac Surg. 1995;59:857-862.

5. Bortolotti U, Scioti G, Milano A, et al. The Edwards Prima stentless valve: hemodynamic performance at one year. Ann Thorac Surg. 1999; 68:2147-2151.

6. David TE, Rpochan GC, Butany JW. Aortic valve replacement with stentless porcine bioprosthesis. J Cardiac Surg. 1988;3:501-505.

7. O'Brien MF. Implantation technique of the CryoLife-O'Brien stentless xenograft aortic valve: the simple, rapid, and correct way to implant and errors to avoid. Semin Thorac Cardiovasc Surg. 1999;11 (Suppl 1):121-125.

8. Myken PS, Caidahl K, Larsson S, et al. 10-year experience with the Biocor porcine bioprosthesis in the aortic position. J Heart Valve Dis. 1994;3:648-656.

9. Musci M, Siniawski H, Pasic M, et al. Surgical therapy in patients with active infective endocarditis: seven-year single centre experience in a subgroup of 255 patients treated with the Shelhigh stentless bioprosthesis. Eur J Cardio Thorac Surg. 2008;34:410-417.

10. D'Onofrio A, Auriemma S, Magagna P, et al. Aortic valve replacement with the Sorin Pericarbon Freedom stentless prosthesis: 7 years' experience in 130 patients. J Thorac Cardiovasc Surg. 2007;134: 491-495.

11. Doss M, Martens S, Wood JP, et al. Aortic leaflet replacement with the new 3F stentless bioprosthesis. Ann Thorac Surg. 2005;79:682-685.

12. Thomas M, Schymic G, Walther T, et al. Thirty-day results of the SAPIEN aortic bioprosthesis European outcome (SOURCE) registry: a European registry of transcatheter aortic valve implantation using the Edwards SAPIEN valve. Circulation. 2010;122:62-69.

13. Piazza N, Grube E, Gerckens U, et al. Procedural and 30-day outcomes following transcatheter aortic valve implantation using the third generation (18Fr) CoreValve ReValving system: results from the multicenter, expanded evaluation registry. 1-year following CE mark approval. EuroIntervention. 2008;4:242-249.

14. Martens S, Ploss A, Sirat S, et al. Sutureless aortic valve replacement with the 3f Enable aortic bioprosthesis. Ann Thorac Surg. 2009;87: 1914-1917.

15. Breitenbach I, Wimmer-Greinecker G, Bockeria LA, et al. Sutureless aortic valve replacement with the Trilogy aortic valve system: multicenter experience. J Thorac Cardiovasc Surg. 2010;140:878-884.

16. Gulbins H, Reichenspurner $H$. Which patients benefit from stentless aortic valve replacement? Ann Thorac Surg. 2009;88:2061-2068.

17. Luciani GB, Casali G, Auriemma S, et al. Survival after stentless and stented xenograft aortic valve replacement: a concurrent, controlled trial. Ann Thorac Surg. 2002;74:1443-1449.

18. Vrandecic M, Fantini FA, Filho BG, et al. Retrospective clinical analysis of stented vs stentless porcine aortic bioprosthesies. Eur J Cardio Thorac Surg. 2000;18:46-53.

19. Ali A, Halstead JC, Cafferty F, et al. Are stentless valves superior to modern stented valves? A prospective randomized trial. Circulation. 2006;114(Suppl I):I535-I540.

20. Chambers JB, Rimington HM, Hodson F, et al. The subcoronary Toronto stentless versus supra-annular Perimount stented replacement aortic valve: early clinical and hemodynamic results of a randomized comparison in 160 patients. J Thorac Cardiovasc Surg. 2006;131: 878-882.

21. Dunning J, Graham RJ, Thambyrajah J, et al. Stentless vs stented aortic valve bioprostheses: a prospective randomized controlled trial. Eur Heart J. 2007;28:2369-2374.

22. Deleuze PH, Fromes Y, Khoung W, et al. Eight-year results of Freestyle stentless bioprosthesis in the aortic position: a single center study of 500 patients. $J$ Heart Valve Dis. 2006;15:247-252.

23. Bach DS, Kon ND, Dumesnil, et al. Ten-year outcome after aortic valve replacement with the Freestyle stentless bioprosthesis. Ann Thorac Surg. $2005 ; 80: 480-486$

24. David TE, Feindel CM, Bos J, et al. Aortic valve replacement with Toronto SPV bioprosthesis: optimal patient survival but suboptimal valve durability. J Thorac Cardiovasc Surg. 2008;135:19-24.
25. Jin XY, Ratnatunga C, Pillai R. Performance of Edwards Prima stentless aortic valve over eight years. Semin Thorac Cardiovasc Surg. 2001;13 (Suppl 1):163-167.

26. Dellegren G, Eriksson MJ, Brodin LA, et al. Eleven years' experience with the Biocor stentless aortic bioprosthesis: clinical and hemodynamic follow-up with long-term relative survival rate. Eur J Cardio Thorac Surg. 2002;22:912-921.

27. Polvani G, Barili F, Dainese L, et al. Long-term results after aortic valve replacement with the Bravo 400 stentless valve. Ann Thorac Surg. 2005;80:495-501.

28. O'Brien MF, Gardner MAH, Garlick B, et al. CryoLife-O’Brien stentless valve: 10-year results of 402 implants. Ann Thorac Surg. 2005;79: 757-766.

29. Musci M, Siniawski H, Pasic M, et al. Surgical therapy in patients with active infective endocarditis: seven-year single centre experience in a subgroup of 255 patients with the Shelhigh stentless bioprosthesis. Eur J Cardio Thorac Surg. 2008;34:410-417.

30. D'Onofrio A, Auriemma S, Magagna P, et al. Aortic valve replacement with the Sorin Pericarbon Freedom stentless prosthesis: 7 years' experience in 130 patients. J Thorac Cardiovasc Surg. 2007;134:491-495.

31. David TE, Puschmann R, Ivanov J, et al. Aortic valve replacement with stentless and stented porcine valves: a case-match study. JThorac Cardiovasc Surg. 1998;116:236-241.

32. Van Nooten, Caes F, François K, et al. Stentless or stented aortic valve implants in elderly patients? Eur J Cardio Thorac Surg. 1999;15: 31-36.

33. Vrandecic M, Fantini FA, Filho BG, et al. Retrospective clinical analysis of stented vs stentless porcine aortic bioprostheses. Eur J Cardio Thorac Surg. 2000;18:46-53.

34. Westaby S, Horton M, Jin XY, et al. Survival advantage of stentless aortic bioprostheses. Ann Thorac Surg. 2000;70:785-791.

35. Luciani GB, Auriemma S, Santini F, et al. Comparison of late outcome after stentless versus stented xenograft aortic valve replacement. Semin Thorac Cardiovasc Surg. 2001;13(Suppl I):I136-I142

36. Tamin M, Bove T, Van Belleghem Y, et al. Stentless vs stented aortic valve replacement: left ventricular mass regression. Asian Cardiovasc Thorac Ann. 2005;13:112-118.

37. Borger MA, Carson SM, Ivanov J, et al. Stentless aortic valve are hemodynamically superior to stented valves during mid-term follow-up: a large retrospective study. Ann Thorac Surg. 2005:80:2180-2185.

38. Bové T, Bellenghem YV, François K, et al. Stentless and stented aortic valve replacement in elderly patients: factors affecting midterm clinical and hemodynamical outcomes. Eur J Cardio Thorac Surg. 2006;30: 706-715.

39. Lehmann S, Walther T, Kempfert J, et al. Stentless versus conventional xenograft aortic valve replacement: midterm results of a prospectively randomized trial. Ann Thorac Surg. 2007;84:467-472.

40. Cohen G, Zagorski B, Christakis GT, et al. Are stentless valves hemodynamically superior to stented valves? Long-term follow up of a randomized trial comparing Carpentier-Edwards pericardial valve with Toronto stentless porcine valves. J Thorac Cardiovasc Surg. 2010;139: 848-859.

41. Levy D, Garrison RJ, Savage DD, et al. Left ventricular mass and incidence of coronary heart disease in an elderly cohort: the Framingham Heart Study. Ann Intern Med. 1989;110:101-107.

42. He GW, Grunkemeier GL, Gately HL, et al. Up to thirty year survival after aortic valve replacement in small aortic root. Ann Thorac Surg. 1995;59:1056-1062.

43. Cohen G, Christakis GT, Joyner CD, et al. Are stentless valves hemodynamically superior to stented valves? A prospective randomized trial. Ann Thorac Surg. 2002;73:767-775.

44. Fries R, Wendler O, Schieffer H, et al. Comparative rest and exercise hemodynamics of 23-mm stentless versus 23-mm stented aortic bioprostheses. Ann Thorac Surg. 2000;69:817-822.

45. Morsy S, Zahran M, Usama M, et al. Hemodynamic performance of stentless porcine bioprosthesis and mechanical bileaflet prosthesis using dobutamine stress echocardiography. Semin Thorac Cardiovasc Surg. 2001;13(Suppl I):I129-I135. 
46. Bevilacqua S, Gianetti J, Ripoli A. Aortic valve disease with severe ventricular dysfunction: stentless valve for better recovery. Ann Thorac Surg. 2002;74:2016-2021.

47. Totaro P, Degno N, Zeidi A, et al. Carpentier-Edwards Perimount magna bioprosthesis: a stented valve with a stentless performance? J Thorac Cardiovasc Surg. 2005;130:1668-1674.

48. Ali A, Halstead JC, Cafferty F. Early clinical and hemodynamic outcomes after stented and stentless aortic valve replacement: results from a randomized controlled trial. Ann Thorac Surg. 2007;83: 2162-2168.

49. Gulbins H, Florath I, Ennker J. Cerebrovascular events after stentless aortic valve replacement during a 9-year follow-up period. Ann Thorac Surg. 2009;86:769-773.

50. Del Rizzo DF, Abdoh A, Cartier P, et al. Factors affecting left ventricular mass regression after aortic valve replacement with stentless valves. Semin Thorac Cardiovasc Surg. 1999;11(Suppl I):I114-I120.

51. Del Rizzo DF, Freed D, Abdoh A, et al. Mid-term results of stented versus stentless valves: does concomitant coronary artery bypass grafting impact survival? Semin Thorac Cardiovasc Surg. 2001;13 (Suppl I):148-155.

52. Kunadian B, Vijayalakshmi K, Thornley AR, et al. Meta-analysis of valve hemodynamics and left ventricular mass regression for stentless versus stented aortic valves. Ann Thorac Surg. 2007;84:73-78.

53. Thomson HL, O'Brien MF, Almeida AA, et al. Haemodynamics and left ventricular mass regression: a comparison of the stentless, stented and mechanical aortic valve replacement. Eur J Cardio Thorac Surg. 1998;13:572-575.

54. Walther T, Falk V, Langebartels G, et al. Regression of left ventricular hypertrophy after stentless versus conventional aortic valve replacement. Semin Thorac Cardiovasc Surg. 1999;11(Suppl I):I18-I21.

55. Maselli D, Pizio R, Bruno LP, et al. Left ventricular mass reduction after aortic valve replacement: homografts, stentless and stented valves. Ann Thorac Surg. 1999;67:966-971.

56. Deeb GM, Smolens IA, Bolling SF, et al. Reoperation for Freestyle stentless aortic valves. Semin Thorac Cardiovasc Surg. 2001;13 (Suppl I):I16-I23.

57. Arenaza DP, Lees B, Flather M, et al. ASSERT (Aortic Stentless versus Stented valve assessment by Echocardiography Randomized Trial) Investigators. Circulation. 2005;112:2696-2702.

58. Bortolotti U, Scioti G, Milano A, et al. The Edwards Prima stentless valve: hemodynamic performance at one year. Ann Thorac Surg. 1999;68:2147-2151.

59. Bach DS, Cartier PC, Kon ND, et al. Impact of implant technique following Freestyle stentless aortic valve replacement. Ann Thorac Surg. 2002;74:1107-1113.

60. Narang S, Satsangi K, Banerjee A, et al. Stentless valves versus stented bioprostheses at the aortic position: midterm results. J Thorac Cardiovasc Surg. 2008;136:943-947.

61. Doss M, Wood MJP, Aybek T, et al. Performance of stentless versus stented aortic valve prostheses in the elderly patients. A prospective randomized trial. Eur J Cardio Thorac Surg. 2003;23:299-304.
62. Risteski PS, Martens S, Rouhollahpour A, et al. Prospective randomized evaluation of stentless vs. stented aortic bioprosthetic valves in the elderly at five years. Inteactive Cardiovasc Thortac Surg. 2009;8: 449-453.

63. De Paulis R, Sommariva L, Colagrande L, et al. Regression of left ventricular hypertrophy after aortic valve replacement for aortic stenosis with different valve substitutes. J Thorac Cardiovasc Surg. 1998;116: 590-598.

64. Silberman S, Shaheen J, Merin O, et al. Exercise hemodynamics of aortic prostheses: comparison between stentless bioprostheses and mechanical valves. Ann Thorac Surg. 2001;72:1217-1221.

65. Walther T, Falk V, Langebartels G, et al. Prospectively randomized evaluation of stentless versus conventional biological aortic valves: impact on early regression of left ventricular hypertrophy. Circulation. 1999;101(Suppl II):II6-II0.

66. Schoen FJ, Levy RJ. Calcification of tissue heart valve substitutes: progress toward understanding and prevention. Ann Thorac Surg. 2005;79:1072-1080.

67. Aupart MR, Mirza A, Meurisse YA, et al. Perimount pericardial bioprosthesis for aortic calcified stenosis. J Heart Valve Dis. 2006;15: 768-776.

68. Mohammadi S, Baillot R, Voisine P, et al. Structural deterioration of the Freestyle aortic valve: mode of presentation and mechanism. J Thorac Cardiovasc Surg. 2006;132:401-406.

69. Machida H, Ishibashi-Ueda H, Nakano K, et al. A morphological study of Carpentier-Edwards pericardial xenografts in the mitral position exhibiting primary tissue failure in adults in comparison with Ionescu-Shiley pericardial xenografts. J Thorac Cardiovasc Surg. 2001;122: 649-655.

70. Pavoni D, Badano LP, Ius F, et al. Limited long-term durability of the Cryolife O'Brien stentless porcine xenograft valve. Circulation. 2007;116(Suppl I):I307-I313.

71. Carrel TP, Schoenhoff FS, Schmidili J, et al. Deleterious outcome of No React-treated stentless valved conduits after aortic root replacement: why were warnings ignored? J Thorac Cardiovasc Surg. 2008;136:52-57.

72. El-Hamamsy I, Zaki M, Stevens LM, et al. Rate of progression and functional significance of aortic root calcification after homograft versus Freestyle aortic root replacement. Circulation. 2009; 120(Suppl 1):S269-S275.

73. Hagl C, Galla JD, Lansman SL, et al. Replacing the ascending aorta and aortic valve for acute prosthetic valve endocarditis: is using prosthetic material contraindicated? Ann Thorac Surg. 2002;74:S1781-S1785.

74. Müller LC, Chevtchik O, Bonatti JO, et al. Treatment of destructive aortic valve endocarditis with the Freestyle aortic root bioprosthesis. Ann Thorac Surg. 2003;75:453-456.

75. Siniawski H, Lehmkuhl H, Weng Y, et al. Stentless aortic valves as an alternative to homografts for valve replacement in active infective endocarditis complicated by ring abscess. Ann Thorac Surg. 2003;75: 803-808.

76. Perrotta S, Lentini S. In patients with severe active aortic valve endocarditis, is a stentless valve as good as homograft? Interactive Cardiovasc Thorac Surg. 2010;11:309-313.

77. Halees ZA, Shahid MA, Sanei AA, et al. Up to 16 years follow-up of aortic valve reconstruction with pericardium: a stentless readily available cheap valve? Eur J Cardio Thorac Surg. 2005;28:200-205.
Vascular Health and Risk Management

\section{Publish your work in this journal}

Vascular Health and Risk Management is an international, peerreviewed journal of therapeutics and risk management, focusing on concise rapid reporting of clinical studies on the processes involved in the maintenance of vascular health; the monitoring, prevention and treatment of vascular disease and its sequelae; and the involvement of

\section{Dovepress}

metabolic disorders, particularly diabetes. This journal is indexed on PubMed Central and MedLine. The manuscript management system is completely online and includes a very quick and fair peer-review system, which is all easy to use. Visit http://www.dovepress.com/ testimonials.php to read real quotes from published authors. 